\title{
Composition and Structure of Ethanol-Lignins of Coniferous and Deciduous Wood and Products of their Catalytic Telomerization with 1,3-Butadiene
}

\author{
Maxim A. Lutoshkin ${ }^{\mathrm{a}}$, \\ Franck Rataboul $^{\mathrm{b}}$, Laurent Djakovitch ${ }^{\mathrm{b}}$, \\ Yuriy N. Malyar ${ }^{\text {a,c }}$ and Boris N. Kuznetsova,c \\ anstitute of Chemistry and Chemical Technology \\ $S B R A S$ \\ Krasnoyarsk, Russian Federation \\ ${ }^{b}$ IRCELYON \\ Lyon, France \\ cSiberian Federal University \\ Krasnoyarsk, Russian Federation
}

Received 29.10.2021, received in revised form 15.11.2021, accepted 30.11.2021

\begin{abstract}
The composition and structure of ethanol-lignins of coniferous (abies, pine) and deciduous (aspen, birch) wood and products of their catalytic telomerization with 1,3-butadiene has been studied with use of the methods ${ }^{31} \mathrm{P}-\mathrm{NMR}$, gel-permeation chromatography, scanning electron microscopy and elemental analysis. Data on the nature and content of hydroxyl groups in ethanollignins were obtained using phosphorylation of lignins with 2-chloro-4,4,5,5,-tetramethyl-1,3,2dioxaphospholane.The studied lignins differ from each other in the content of aliphatic, phenolic and carboxyl groups. The total content of hydroxyl groups increases in the series of ethanol-lignins: birch $<$ aspen $<$ pine $<$ abies. For the modification of ethanol-lignins, the reaction of catalytic telomerization with 1,3 -butadiene was used at $70{ }^{\circ} \mathrm{C}$ and $90{ }^{\circ} \mathrm{C}$ in the presence of a complex of palladium (II) diacetate with the sodium salt of triphenylphosphine trisulfate. By comparing the number of aliphatic, phenolic and carboxyl $\mathrm{OH}$ - groups in the initial and telomerized ethanol-lignins, it was found that only aliphatic and phenolic hydroxyl groups participate in the telomerization reaction. Telomerization of ethanol-lignins with 1,3-butadiene increases their average molecular weight and reduces polydispersity. The morphology of telomerized and initial samples of ethanollignins varies significantly.
\end{abstract}

(C) Siberian Federal University. All rights reserved This work is licensed under a Creative Commons Attribution-NonCommercial 4.0 International License (CC BY-NC 4.0).

* Corresponding author E-mail address: maximsfu@yahoo.com 
Keywords: ethanol-lignin, abies, pins, aspen, birch, OH-groups, content, ${ }^{31} \mathrm{P}-\mathrm{NMR}$, catalytic telomerization, 1,3-butadiene.

Acknowledgments. This work was supported by the Russian Science Foundation (grant No. 21-1300250), using the equipment of Krasnoyarsk Regional Research Equipment Centre of SB RAS.

\title{
Состав и строение этаноллигнинов хвойной
}

и лиственной древесины и продуктов

\section{их каталитической теломеризации с 1,3-бутадиеном}

\author{
М. А. Лутошкин ${ }^{a}$, Ф. Ратабоул ${ }^{0}$, \\ Л. Дьякович ${ }^{\sigma}$ Ю.Н. Маляр ${ }^{\text {a, }}$, Б. Н. Кузнецов ${ }^{a, \mathrm{~B}}$ \\ ${ }^{a}$ Институт химии и химической технологии \\ ФИЦ КНЦ СО РАН \\ Российская Федерачия, Красноярск \\ ${ }^{\sigma} I R C E L Y O N$ \\ Lyon, France \\ ${ }^{6}$ Сибирский федеральный университет \\ Российская Федераиия, Красноярск
}

\begin{abstract}
Аннотация. Методами ${ }^{31}$ Р-ЯМР, гель-проникающей хроматографии, сканирующей электронной микроскопии и элементного анализа изучены состав и строение этаноллигнинов хвойной (пихта, сосна) и лиственной (осина, береза) древесин и продуктов их каталитической теломеризации 1,3-бутадиеном. Данные о природе и количестве гидроксильных групп в этаноллигнинах получены с использованием фосфорилирования лигнинов 2-хлоро-4,4,5,5,-тетраметил-1,3,2диоксафосфоланом. Изученные этаноллигнины отличаются друг от друга содержанием алифатических, фенольных и карбоксильных групп. Общее количество гидроксильных групп увеличивается в ряду этаноллигнинов: березы / осины / сосны / пихты. Для модификации свойств этаноллигнинов использована реакция каталитической теломеризации с 1,3-бутадиеном при 70 и $90^{\circ} \mathrm{C}$ в присутствии комплекса диацетата палладия (II) с натриевой солью трисульфата трифенилфосфина. Путем сопоставления количества алифатических, фенольных и карбоксильных ОН-групп в исходных и теломеризованных этаноллигнинах установлено, что в реакции теломеризации участвуют только алифатические и фенольные гидроксильные группы. Теломеризация этаноллигнинов 1,3-бутадиеном увеличивает их среднюю молекулярную массу и снижает полидисперсность. Морфология теломеризованных и исходных образцов этаноллигнинов существенно различается.
\end{abstract}


Ключевые слова: этаноллигнин, пихты, сосны, осины, березы, ОН-группы, содержание, ${ }^{31} \mathrm{P}-Я М Р$, каталитическая теломеризация,1,3-бутадиен.

Благодарности. Работа выполнена при финансовой поддержке Российского научного фонда (грант № 21-13-00250) с использованием оборудования Красноярского регионального центра коллективного пользования ФИЦ КНЦ СО РАН.

Цитирование: Лутошкин, М.А. Состав и строение этаноллигнинов хвойной и лиственной древесины и продуктов их каталитической теломеризации с 1,3-бутадиеном / М.А. Лутошкин, Ф. Ратабоул, Л. Дьякович, Ю.Н. Маляр, Б. Н. Кузнецов // Журн. Сиб. федер. ун-та. Химия, 2021, 14(4). С. 539-551. DOI: 10.17516/1998-2836-0261

\section{Введение}

Огромные ресурсы возобновляемой лигниноцеллюлозной биомассы представлены древесиной, которая состоит из трех основных компонентов: целлюлозы, лигнина, гемицеллюлозы [1]. Традиционные технологии химической переработки древесины направлены на получение целевых продуктов преимущественно из целлюлозы, при этом лигнин остается крупнотоннажным отходом [2].

Перспективные технологии глубокой переработки древесины ориентированы на использование всех основных компонентов биомассы [3-5]. Одной из наиболее актуальных задач является разработка высокотехнологичных методов утилизации лигнина.

Лигнин - ароматический полимер, содержание которого в древесине достигает 30 мас.\%. Он состоит из гваяцильных, сирингильных и гидроксифенилпропановых мономерных единиц, связанных между собой углерод-кислородными и углерод-углеродными связями. Лигнины хвойных пород в основном состоят из структур гваяцильного типа с небольшим количеством структур сирингильного и р-гидроксифенильного типов. Лигнины лиственных пород преимущественно содержат структуры сирингильного типа и небольшое количество гваяцильных компонентов.

В настоящее время исследуются различные пути переработки лигнина в ценные химические продукты, основные из них деполимеризация до мономерных соединений и химическая модификация. [7-11] Химическая модификация лигнинов используется для получения новых функциональных полимеров, например биологически активных сульфатированных лигнинов [10]. При этом предпочтение отдается использованию органосольвентных лигнинов, образующихся при получении целлюлозы в среде органических растворителей [12]. Органосольвентные лигнины в отличие от традиционных технических лигнинов не содержат серы и неорганических примесей, имеют менее конденсированную структуру и обладают повышенной реакционной способностью.

Введение новых функциональных групп в структуру органосольвентных лигнинов позволит изменять их растворимость, гидрофобность, биологическую активность и другие свойства. В частности, гидроксильные группы лигнина могут участвовать в реакциях сополимеризации (теломеризации) с непредельными легкими углеводородами, например с пропандиеном или 1,3-бутадиеном.

На примере полисахаридов (крахмала) было показано, что свойства продуктов их каталитической теломеризации с 1,3-бутадиеном могут существенно отличаться от свойств исходных

$$
-541-
$$


полимеров $[13,14]$. В настоящее время в литературе отсутствуют сведения о процессах теломеризации лигнинов с диенами.

Целью настоящей работы являлось изучение состава и строения этаноллигнинов различных пород древесины и продуктов их каталитической теломеризации с 1,3-бутадиеном.

\section{Экспериментальная часть}

В качестве объектов исследования были выбраны этаноллигнины, выделенные из опилок различных видов древесины - сосны, пихты, осины, березы. Этаноллигнины получали обработкой древесных опилок 60\%-ным водным раствором этанола в автоклаве при температуре $180{ }^{\circ} \mathrm{C}$ в течение 2 ч по методике [15].

Теломеризацию этаноллигнинов 1,3-бутадином проводили следующим образом.

Навеску этаноллигнина (0,35 г) растворяли в 70 мл дистиллированной воды с добавлением 0,35 г гидроксида натрия. Катализатор готовили, добавляя в приготовленный раствор этаноллигнина 69 мг натриевой соли трисульфата трифенилфосфина и 13 мг диацетата палладия. Раствор переносили в стальной реактор объемом $100 \mathrm{~cm}^{3}$, после чего свободный объем запол-

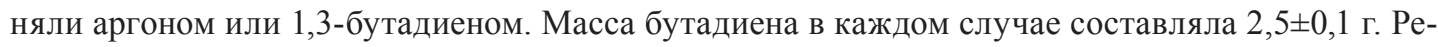
акцию теломеризации проводили в течении 2 ч при температурах 70 и $90^{\circ} \mathrm{C}$ при интенсивном перемешивании. После завершения реакции теломеризованный лигнин осаждали из раствора $10 \%$-ным раствором соляной кислоты. Осадок отделяли центрифугированием и промывали дистиллированной водой.

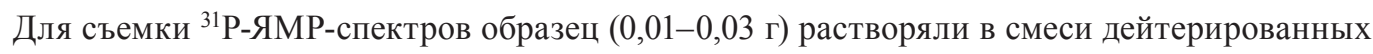
растворителей ДМФ/пиридин(1:1v/v) с добавлением циклогексанола в качестве стандарта. Для фосфорилирования образцов лигнина использовали 2-хлоро-4,4,5,5-тетраметил-1,3,2-диоксофосфалан, который добавляли в количестве 0,1 г (рис. 1). Также к смеси добавляли дейтерированный хлороформ.

ЯМР-спектры (включая двухмерные) были записаны при $25{ }^{\circ} \mathrm{C}$ на спектрометре Bruker AVANCEIII (600 MHz $\left({ }^{1} \mathrm{H}\right)$ и $\left.155 \mathrm{MHz}\left({ }^{13} \mathrm{C}\right), 240 \mathrm{MHz}\left({ }^{31} \mathrm{P}\right)\right)$ Красноярского центра коллективного пользования. Концентрацию ОН-групп рассчитывали по интегральной интенсивности соответствующих областей, сравнивая их с площадью пика стандарта циклогексанола.

Молекулярно-массовое распределение образцов определяли на многодетекторной системе GPC / SEC Agilent 1200 Infinity II с тройным детектированием: рефрактометром (PL), вискозиметром (VS) и светорассеянием (LS). Разделение проводили на двух колонках Aquagel-OH Mixed-M (300 × 7,5 мм, 8 мкм), используя хлороформ в качестве подвижной фазы. Колонку<smiles>COc1cc(I)cc(I)c1OI1OC(C)(C)C(C)(C)O1</smiles>

Рис. 1. Фосфорилирование лигнинов

Fig. 1. Phosphorylation of lignins 
калибровали по стандартам полиэтиленгликоля (Agilent, Санта-Клара, Калифорния, США). Скорость потока элюента составляла 1 мл / мин, а объем пробы - 100 мкл. Перед анализом образцы растворяли в подвижной фазе (1 мг / мл) и фильтровали через гидрофильный мембранный фильтр из PTFE0,22 мкм (Agilent). Сбор и обработка данных выполнялись с помощью программного обеспечения Agilent GPC / SEC MDS.

Элементный анализ лигнинов выполнен на элементном анализаторе FlashEA-1112 (ThermoQuest, Италия).

\section{Результаты и обсуждение}

Определение содержания гидроксильных групп в этаноллигнинах

Данные элементного анализа древесных этаноллигнинов приведены в табл. 1.

В структуре лигнина содержатся разнообразные ОН-группы, способные участвовать в реакции теломеризации с 1,3-бутадиеном. С использованием метода ${ }^{31} \mathrm{P}-Я М Р$ установлена природа и содержание различных гидроксильных групп в этаноллигнинах лиственной и хвойной древесины.

Таблица 1. Элементный состав древесных этаноллигнинов*

Table 1. Elemental composition of wood ethanol-lignins*

\begin{tabular}{|c|c|c|c|}
\hline Этаноллигнин & С (\%, мас.) & Н (\%, мас.) & $\mathrm{O}_{\text {dif }}(\%$, мас.) \\
\hline Пихты & 66,34 & 5,94 & 27,54 \\
\hline Сосны & 65,28 & 6,06 & 29,49 \\
\hline Осины & 63,01 & 6,26 & 30,73 \\
\hline Березы & 63,62 & 6,04 & 30,34 \\
\hline
\end{tabular}

* - содержание кислорода рассчитано по разнице.

Интегрирование площадей пиков в ЯМР-спектре позволяет дифференцировать различные типы ОН-групп и рассчитывать их содержание в этаноллигнинах. Типичный ${ }^{31} \mathrm{P}-Я \mathrm{MP-спектр}$ изображен на рис. 2.

В спектре можно выделить несколько областей, соответствующих различным ОН-группам: область от 150 до 145,5 ppm соответствует алифатическим ОН-группам, пик при 139 ррт принадлежит циклогексанолу, используемому в качестве стандарта, область при 144,7-136,6 ppm соответствует фенольным ОН-группам, при 133,6-136,6 - карбоксильным группам [16]. Инфор-

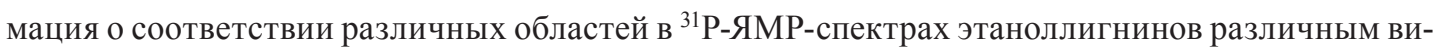
дам связей приведена в табл. 2.

Интегрирование этих областей с учетом концентрации стандарта (циклогексанола) позволяет вычислить содержание в этаноллигнинах основных типов гидроксильных групп: алифатических (спиртовых), фенольных и карбоксильных. Фенольные группы в свою очередь могут быть дифференцированы на некоторые подтипы ( $-\beta-5,-4-\mathrm{O}-5,-5-5$ связи). Также в ЯМР-спектрах могут быть выделены гваяцильные и катехильные группы. В табл. 3 приведены данные о содержании различных фракционных групп в этаноллигнинах.

$$
-543-
$$




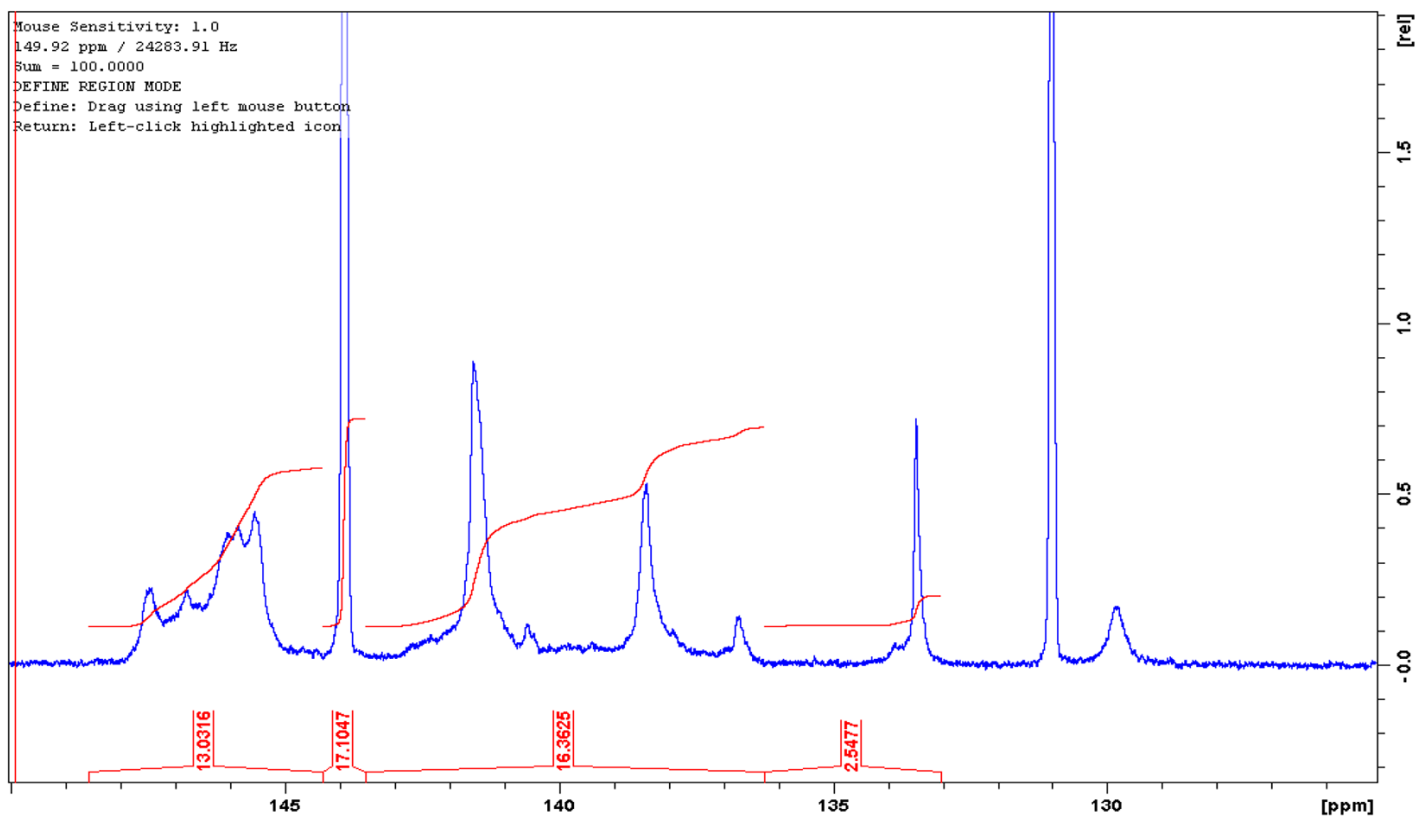

Рис. 2. ${ }^{31}$ Р-ЯМР-спектр этаноллигнина пихты

Fig. 2. ${ }^{31} \mathrm{P}-\mathrm{NMR}$ spectrum of abies ethanol-lignin

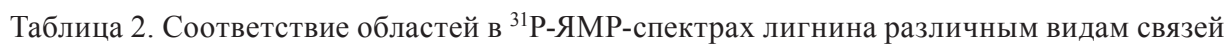

Table 2. Correspondence of regions in the lignin ${ }^{31} \mathrm{P}-\mathrm{NMR}$ spectra to different types of bonds

\begin{tabular}{|l|c|}
\hline \multicolumn{1}{|c|}{ Тип ОН-групп } & Интервал, ppm \\
\hline Алифатические & $150,0-145,5$ \\
\hline Фенольные & $144,7-136,6$ \\
\hline Пара-ОН-фенольные и гваяцильные & $137,3-140,0$ \\
\hline С5 замещенные, включая: & $140,0-144,7$ \\
\hline$-\beta-5$ & $142,8-144,7$ \\
\hline$-4-О-5$ & $141,7-142,8$ \\
\hline$-5-5$ & $140,2-141,7$ \\
\hline Гваяцильные & $139,0-140,0$ \\
\hline Катехильные & $138,0-139,0$ \\
\hline Пара-гидрокси-фенольные & $138,0-137,3$ \\
\hline Карбоксильные & $133,6-136,6$ \\
\hline
\end{tabular}

Исследуемые этаноллигнины содержат от 6,1 до 5,5 ммоль ОН-групп на 1 г полимера.

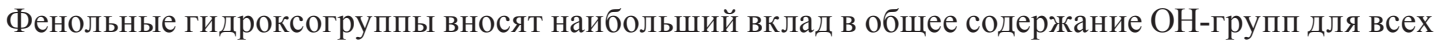
изучаемых этаноллигнинов. Максимальное содержание ОН-групп наблюдается для этаноллигнина пихты, минимальное - для этаноллигнина березы. Общее количествоОН-групп увеличивается в ряду этаноллигнинов: березы<осины<сосны<пихты. 
Таблица 3. Содержание различных ОН-групп в этаноллигнинах (ммоль/г)

Table 3. Content of different $\mathrm{OH}$-groups in ethanol-lignins $(\mathrm{mmol} / \mathrm{g})$

\begin{tabular}{|l|c|c|c|c|}
\hline \multirow{2}{*}{ Типфункциональных групп } & \multicolumn{3}{|c|}{ Этаноллигнины } & березы \\
\cline { 2 - 5 } & пихты & сосны & осины & $1,77 \pm 0,11$ \\
\hline Алифатические & $2,27 \pm 0,03$ & $2,53 \pm 0,17$ & $2,3 \pm 0,2$ & $3,29 \pm 0,02$ \\
\hline Фенольные-ОН & $3,45 \pm 0,05$ & $2,88 \pm 0,08$ & $2,8 \pm 0,2$ & $2,18 \pm 0,02$ \\
\hline С5-замещенные, включая: & $0,81 \pm 0,02$ & $0,74 \pm 0,02$ & $1,9 \pm 0,1$ & $0,16 \pm 0,02$ \\
\hline - -5 & $0,15 \pm 0,03$ & $0,11 \pm 0,01$ & $0,17 \pm 0,02$ & $0,66 \pm 0,10$ \\
\hline -4-О-5 & $0,19 \pm 0,01$ & $0,164 \pm 0,005$ & $0,36 \pm 0,02$ & $1,3 \pm 0,1$ \\
\hline -5-5 & $0,39 \pm 0,01$ & $0,36 \pm 0,02$ & $1,3 \pm 0,1$ & $0,22 \pm 0,03$ \\
\hline Гваяцильные & $0,415 \pm 0,002$ & $0,36 \pm 0,01$ & $0,18 \pm 0,01$ & $0,72 \pm 0,03$ \\
\hline Катехильные & $1,5 \pm 0,1$ & $1,6 \pm 0,1$ & $0,61 \pm 0,01$ & $0,14 \pm 0,01$ \\
\hline Пара-гидрокси - фенольные & $0,44 \pm 0,04$ & $0,13 \pm 0,01$ & $0,23 \pm 0,01$ & $0,40 \pm 0,01$ \\
\hline Карбоксильные & $0,33 \pm 0,01$ & $0,29 \pm 0,01$ & $0,48 \pm 0,02$ & 0 \\
\hline
\end{tabular}

\section{Изучение термической устойчивости растворенных этаноллигнинов}

Проведена серия экспериментов по изучению термической устойчивости этаноллигнинов в водно-щелочной среде в отсутствие и в присутствии катализатора теломеризации (комплекс диацетатапалладия(II) с натриевой солью трисульфата трифенилфосфина). Для этого проведено сопоставление содержания различных гидроксильных групп в исходных и термообработанных этаноллигнинах (табл. 4).

Практически для всех термообработанных образцов наблюдается снижение содержания алифатическихи фенольных ОН-групп и возрастание концентрации карбоксильных групп после выдержки исходных этаноллигнинов в водно-щелочной среде при температурах 70 и $90{ }^{\circ} \mathrm{C}$. Следует отметить, что минимальным изменениям при термообработке подвергается этаноллигнин березы.

Результаты изучения термической устойчивости растворенных этаноллигнинов свидетельствуют о сохранении достаточного количества ОН-групп, способных участвовать в реакции теломеризации с 1,3-бутадиеном при температурах 70 и $90{ }^{\circ} \mathrm{C}$.

\section{Изучение теломеризации этаноллигнинов с 1,3-бутадиеном}

О протекании реакции теломеризации судили по содержанию гидроксильных групп в исходных этаноллигнинах и продуктах их теломеризации.

Как следует из полученных результатов (табл. 5), содержание алифатических, фенольных и карбоксильных ОН-групп в исходных и теломеризованных этаноллигнинах может существенно различаться.

По сравнению с исходными этаноллигнинами пихты и осины продукты их теломеризации содержат меньше алифатических и фенольных ОН-групп. При теломеризации этаноллигнина сосны содержание этих групп мало изменяется, а в случае этаноллигнина березы может возрастать. Содержание карбоксильных групп в продуктах теломеризации всех видов этаноллигнинов больше, чем в исходных этаноллигнинах. На содержание различных видов ОН-групп

$$
-545-
$$


Таблица 4. Содержание ОН-групп в этаноллигнинах после их выдержки в растворе 2 \% $\mathrm{NaOH}$ при 70 и $90{ }^{\circ} \mathrm{C}$ (ммоль/г)

Table 4. Content of $\mathrm{OH}$-groups in ethanol-lignins after their exposure in a solution of $2 \% \mathrm{NaOH}$ at 70 and $90{ }^{\circ} \mathrm{C}$ $(\mathrm{mmol} / \mathrm{g})$

\begin{tabular}{|c|c|c|c|c|c|}
\hline \multicolumn{6}{|c|}{ Этаноллигнин пихты } \\
\hline $\begin{array}{c}\text { Гидроксильные } \\
\text { группы }\end{array}$ & \multicolumn{2}{|c|}{$\begin{array}{c}\text { В отсутствие катализатора } \\
( \pm 0,05)\end{array}$} & \multicolumn{2}{|c|}{$\begin{array}{c}\text { В присутствии катализатора } \\
( \pm 0,05)\end{array}$} & \multirow{2}{*}{$\begin{array}{c}\text { Исходный } \\
\text { этаноллигнин } \\
\text { - }\end{array}$} \\
\hline & 70 & 90 & 70 & 90 & \\
\hline Алифатические & 1,75 & 1,76 & 1,69 & 1,62 & $2,27 \pm 0,03$ \\
\hline Фенольные & 3,50 & 2,63 & 2,82 & 2,36 & $3,45 \pm 0,05$ \\
\hline Карбоксильные & 0,58 & 0,55 & 0,54 & 0,65 & $0,33 \pm 0,01$ \\
\hline Всего & 5,83 & 4,94 & 5,05 & 4,63 & $6,10 \pm 0,05$ \\
\hline \multicolumn{6}{|c|}{ Этаноллигнин сосны } \\
\hline $\begin{array}{c}\text { Гидроксильные } \\
\text { группы }\end{array}$ & \multicolumn{2}{|c|}{$\begin{array}{l}\text { В отсутствие катализатора } \\
( \pm 0,05)\end{array}$} & \multicolumn{2}{|c|}{$\begin{array}{c}\text { В присутствии катализатора } \\
( \pm 0,05)\end{array}$} & $\begin{array}{c}\text { Исходный } \\
\text { этаноллигнин }\end{array}$ \\
\hline & 70 & 90 & 70 & 90 & - \\
\hline Алифатические & 1,90 & 2,19 & 1,83 & 2,36 & $2,53 \pm 0,17$ \\
\hline Фенольные & 2,44 & 3,20 & 3,27 & 3,31 & $2,88 \pm 0,08$ \\
\hline Карбоксильные & 0,52 & 0,68 & 0,43 & 0,62 & $0,29 \pm 0,01$ \\
\hline Всего & 4,85 & 6,07 & 5,53 & 6,28 & $5,70 \pm 0,23$ \\
\hline \multicolumn{6}{|c|}{ Этаноллигнин осины } \\
\hline $\begin{array}{c}\text { Гидроксильные } \\
\text { группы }\end{array}$ & \multicolumn{2}{|c|}{$\begin{array}{c}\text { В отсутствие катализатора } \\
( \pm 0,05)\end{array}$} & \multicolumn{2}{|c|}{$\begin{array}{c}\text { В присутствии катализатора } \\
( \pm 0,05)\end{array}$} & $\begin{array}{c}\text { Исходный } \\
\text { этаноллигнин }\end{array}$ \\
\hline & 70 & 90 & 70 & 90 & - \\
\hline Алифатические & 1,96 & 1,68 & 1,94 & 1,66 & $2,30 \pm 0,2$ \\
\hline Фенольные & 1,92 & 1,90 & 2,21 & 2,69 & $2,80 \pm 0,2$ \\
\hline Карбоксильные & 0,74 & 0,54 & 0,68 & 0,60 & $0,48 \pm 0,02$ \\
\hline Всего & 4,60 & 4,10 & 4,80 & 4,95 & $5,60 \pm 0,3$ \\
\hline \multicolumn{6}{|c|}{ Этаноллигнин березы } \\
\hline $\begin{array}{c}\text { Гидроксильные } \\
\text { группы }\end{array}$ & \multicolumn{2}{|c|}{$\begin{array}{c}\text { В отсутствие катализатора } \\
( \pm 0,05)\end{array}$} & \multicolumn{2}{|c|}{$\begin{array}{c}\text { В присутствии катализатора } \\
( \pm 0,05)\end{array}$} & $\begin{array}{c}\text { Исходный } \\
\text { этаноллигнин }\end{array}$ \\
\hline & 70 & 90 & 70 & 90 & - \\
\hline Алифатические & 1,92 & 1,55 & 1,88 & 2,17 & $1,77 \pm 0,11$ \\
\hline Фенольные & 3,30 & 3,42 & 2,93 & 3,28 & $3,29 \pm 0,02$ \\
\hline Карбоксильные & 0,76 & 0,72 & 0,72 & 0,86 & $0,40 \pm 0,01$ \\
\hline Всего & 5,98 & 5,69 & 5,54 & 6,31 & $5,46 \pm 0,12$ \\
\hline
\end{tabular}

в теломеризованных этаноллигнинах оказывает влияние и температура реакции теломеризации (табл. 5). Так, продукт теломеризации этаноллигнина березы при $90^{\circ} \mathrm{C}$ содержит больше алифатических и фенольных ОН-групп (2,48 и 4,15 ммоль/г), чем исходный этаноллигнин $(1,77$ и 3,29 ммоль/г), причем их содержание существенно уменьшается (до 1,89 и 2,79 ммоль/г) при снижении температуры теломеризации до 70 으. Повышение количества ОН-групп в продуктах теломеризации этаноллигнина березы при $90{ }^{\circ} \mathrm{C}$ может быть связано с протеканием реакции гидролиза эфирных связей лигнина в водно-щелочной среде. 
Таблица 5. Содержание различных ОН-групп в исходных и теломеризованных этаноллигнинах (ммоль/г)

Table 5. Content of different OH-groups in the initial and telomerized ethanol-lignins $(\mathrm{mmol} / \mathrm{g})$

\begin{tabular}{|c|c|c|c|}
\hline \multicolumn{4}{|c|}{ Этаноллигнин пихты } \\
\hline Параметры & Исходный этаноллигнин & \multicolumn{2}{|c|}{ Продукт теломеризации $( \pm 0,02)$} \\
\hline $\mathrm{T},{ }^{\circ} \mathrm{C}$ & - & 70 & 90 \\
\hline Алифатические & $2,27 \pm 0,03$ & 1,95 & 1,82 \\
\hline Фенольные & $3,45 \pm 0,05$ & 2,17 & 3,05 \\
\hline Карбоксильные & $0,33 \pm 0,01$ & 0,59 & 0,80 \\
\hline Всего & $6,10 \pm 0,05$ & 4,71 & 5,67 \\
\hline \multicolumn{4}{|c|}{ Этаноллигнин сосны } \\
\hline Параметры & Исходный этаноллигнин & \multicolumn{2}{|c|}{ Продукт теломеризации $( \pm 0,02)$} \\
\hline $\mathrm{T},{ }^{\circ} \mathrm{C}$ & - & 70 & 90 \\
\hline Алифатические & $2,53 \pm 0,17$ & 2,16 & 2,43 \\
\hline Фенольные & $2,88 \pm 0,08$ & 2,61 & 2,86 \\
\hline Карбоксильные & $0,29 \pm 0,01$ & 0,53 & 0,67 \\
\hline Всего & $5,70 \pm 0,23$ & 5,30 & 5,96 \\
\hline \multicolumn{4}{|c|}{ Этаноллигнин осины } \\
\hline Параметры & Исходный этаноллигнин & \multicolumn{2}{|c|}{ Продукт теломеризации $( \pm 0,02)$} \\
\hline $\mathrm{T},{ }^{\circ} \mathrm{C}$ & - & 70 & 90 \\
\hline Алифатические & $2,30 \pm 0,20$ & 1,13 & 1,69 \\
\hline Фенольные & $2,80 \pm 0,20$ & 0,92 & 1,41 \\
\hline Карбоксильные & $0,48 \pm 0,02$ & 0,49 & 0,51 \\
\hline Всего & $5,60 \pm 0,30$ & 2,50 & 3,60 \\
\hline \multicolumn{4}{|c|}{ Этаноллигнин березы } \\
\hline Параметры & Исходный этаноллигнин & \multicolumn{2}{|c|}{ Продукт теломеризации $( \pm 0,02)$} \\
\hline $\mathrm{T},{ }^{\circ} \mathrm{C}$ & - & 70 & 90 \\
\hline Алифатические & $1,77 \pm 0,11$ & 1,89 & 2,48 \\
\hline Фенольные & $3,29 \pm 0,02$ & 2,79 & 4,15 \\
\hline Карбоксильные & $0,40 \pm 0,01$ & 0,69 & 0,55 \\
\hline Всего & $5,46 \pm 0,12$ & 5,37 & 7,18 \\
\hline
\end{tabular}

Методом гель-проникающей хроматографии изучено молекулярно-массовое распределение (ММР) исходных и теломеризованных этаноллигнинов пихты и осины (рис. 3). Таблица 6 содержит данные о средних молекулярных массах и полидисперсности образцов исходных и теломеризованных этаноллигнинов. В случае теломеризованных этаноллигнинов пихты и осины наблюдается увеличение средней молекулярной массы и снижение полидисперсности по сравнению с исходными этаноллигнинами. Также в случае теломеризованных этаноллигнинов наблюдается исчезновение пика низкомолекулярной фракции, присутствующего на кривых ММР исходных этаноллигнинов.

Отсутствие низкомолекулярных фракций в теломеризованных этаноллигнинах может свидетельствовать о «сшивании» макромолекул лигнина между собой через присоединившиеся молекулы 1,3-бутадиена, что приводит к увеличению их молекулярной массы. Кривые 

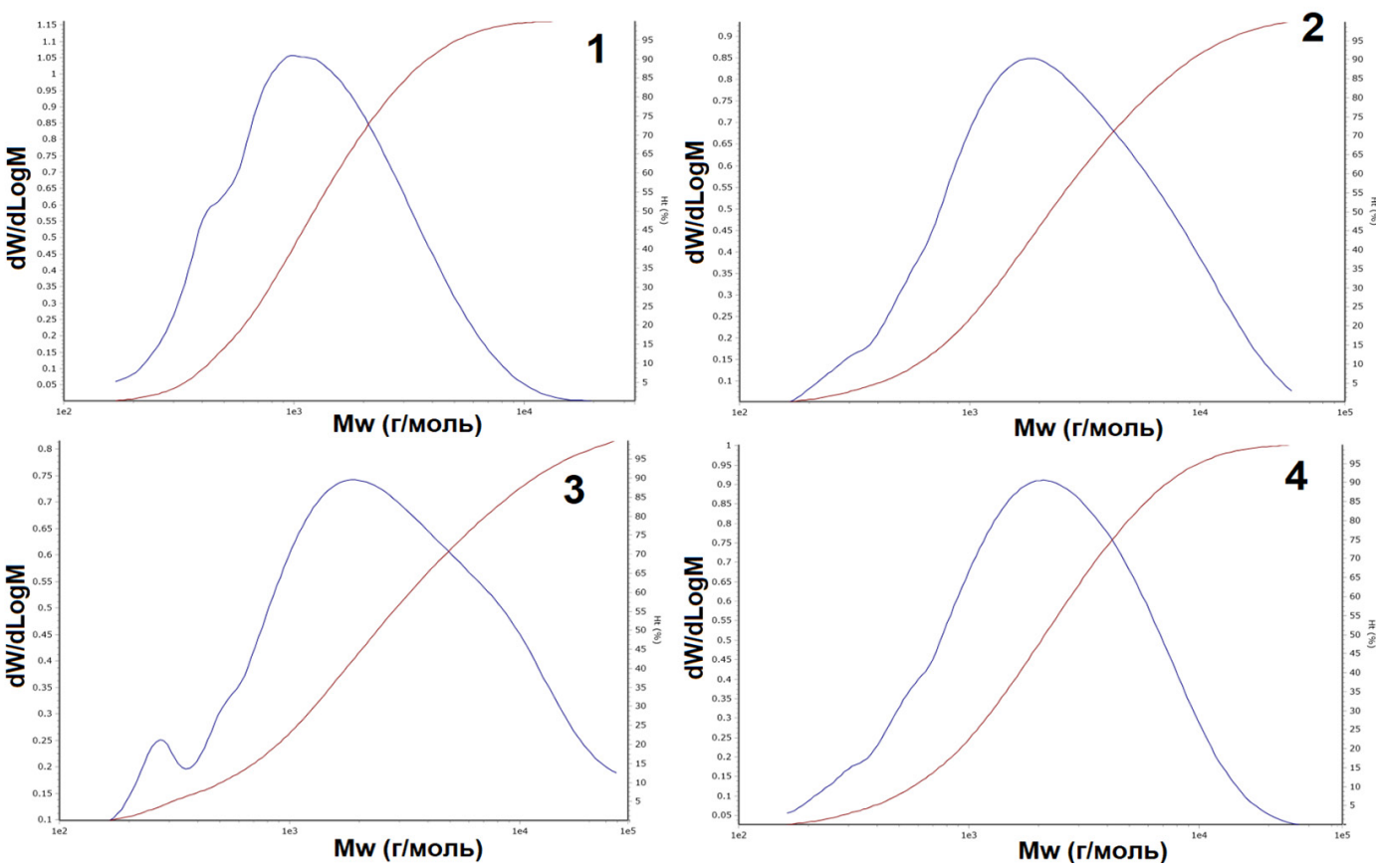

Рис. 3. Кривые молекулярно-массового распределения для этаноллигнинов пихты (1 - до, 2 - после теломеризации) и осины(3 - до, 4 - после теломеризации)

Fig. 3. Molecular mass distribution curves for abies ethanol-lignin ( 1 - before, 2 - after telomerization) and foraspen ethanol-lignin ( 3 - before, 4 - after telomerization)

Таблица 6. Средние молекулярные массы (Mn, Mw) и полидисперсность (D) исходных и теломеризованных этаноллигнинов

Table 6. Average molecular mass (Mn, Mw) and polydispersity (D) of the initial and telomerized ethanol-lignins

\begin{tabular}{|l|c|c|c|}
\hline \multicolumn{1}{|c|}{ Образец } & Mn (Da) & Mw (Da) & D \\
\hline Этаноллигнин пихты (исходный) & 950 & 1830 & 1,95 \\
\hline Этаноллигнин пихты (после теломеризации) & 1350 & 2320 & 1,73 \\
\hline Этаноллигнин осины (исходный) & 1104 & 1436 & 1,50 \\
\hline Этаноллигнин осины (после теломеризации) & 1583 & 2480 & 1,32 \\
\hline
\end{tabular}

молекулярно-массового распределения теломеризованных этаноллигнинов сосны и березы не удалось получить из-за малой растворимости этих лигнинов в элюенте.

Данные о морфологии исходного и теломеризованного этаноллигнина пихты получены методом сканирующей электронной микроскопии (рис. 4).

В процессе теломеризации этаноллигнина с 1,3-бутадиеном существенно изменяется его морфология, а именно его изначально аморфная структура трансформируется в более пористую и более четко фрагментированную. Аналогичная картина наблюдается и при теломеризации этаноллигнинов сосны, осины и березы. 

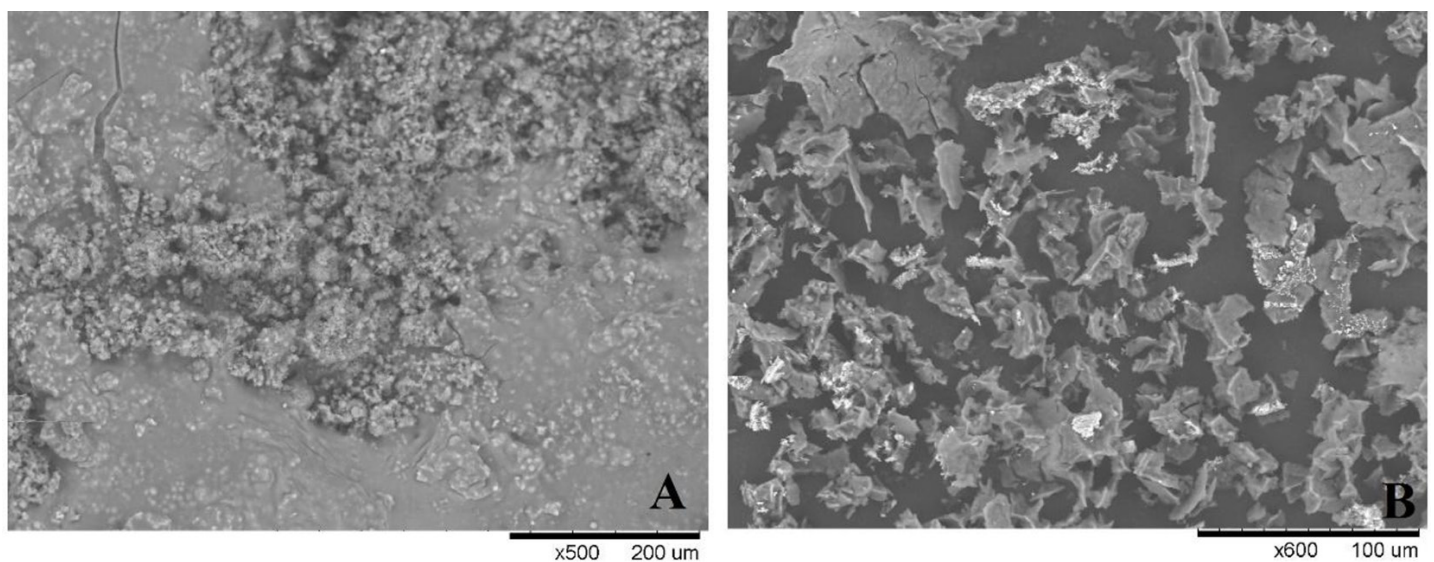

Рис. 4. СЭМ-изображения исходного (А) и теломеризованного (В) этаноллигнина пихты

Fig. 4. SEM images of initial (A) and telomerized (B) abiesethanol-lignin

\section{Заключение}

Методами ${ }^{31} \mathrm{P}-Я М Р$, гель-проникающей хромотографии и сканирующей электронной микроскопии охарактеризованы этаноллигнины, выделенные из древесины пихты, сосны, осины и березы.

По данным ЯМР, изученные этаноллигнины отличаются друг от друга содержанием различных функциональных групп. Однако общее содержание в них алифтических, фенольных и карбоксильных групп различается незначительно (5,46-6,10 ммоль/г).

Этаноллигнины были модифицированы теломеризацией 1,3-бутадиеном при 70 и $90{ }^{\circ} \mathrm{C}$ в присутствии катализатора - комплекса диацетата $\mathrm{Pd}(\mathrm{II})$ с натриевой солью трисульфата трифенилфосфина. Холостыми экспериментами в атмосфере аргона установлено, что при этих температурах происходит снижение в растворенных этаноллигнинах содержания алифатических и фенольных гидроксильных групп и возрастание количества карбоксильных ОН-групп, однако их общее содержание мало изменяется.

Сопоставление содержания различных ОН-групп в исходных этаноллигнинах и в продуктах их теломеризации показало, что в реакции теломеризации участвуют алифатические и фенольные гидроксильные группы.

Методом гель-проникающей хромотографии установлено, что в случае теломеризованных этаноллигнинов пихты и осины наблюдается увеличение средней молекулярной массы и снижение полидисперсности по сравнению с исходными этаноллигнинами.

По данным сканирующей электронной микроскопии, изначально аморфная структура этаноллигнинов трансформируется при теломеризации в более пористую и более четко фрагментированную.

Теломеризованные этаноллигнины являются более гидрофобными по сравнению с исходными и имеют перспективы использования в качестве сорбентов, гидроизоляционных материалов, в косметической промышленности, при получении композитных материалов. 


\section{Список литературы / References}

1. Toebes M.L., van Dillen J. A., de Jong K. P. Synthesis of supported palladium catalysts. Journal of Molecular Catalysis A: Chemical 2001. Vol. 173(1). P. 75-98.

2. Rowell R. M. Handbook of wood chemistry and wood composites. Madison: CRC Press, Boca Raton, 2012. $592 \mathrm{p}$.

3. Sixta H. Handbook of pulp, Weinheim: Wiley-VCH Verlag GmbH \& Co, 2006. 1352 p.

4. Kuznetsov B. N., Sudakova I.G., Garyntseva N. V., Levdansky V.A., Ivanchenko N. M., Pestunov A. V., Djakovitch L., Pinel C. Green biorefinery of larch wood biomass to obtain the bioactive compounds, functional polymers and nanoporous materials. Wood Science and Technology. 2018. Vol. 52. P. 1377-1394.

5. Van den Bosch S., Schutyser W., Vanholme R., Drissen T., Koelewijn S.F., Renders T., De Meester B., Huijgen W. J.J., Dehaen W., Courtin C.M., Lagrain B., Boerjan W., Sels B. F. Reductive lignocellulose fractionation into soluble lignin-derived phenolic monomers and dimers and processable carbohydrate pulps. Energy Environ Sci. 2015. Vol. 8. P. 1748-1763.

6. Kuznetsov B.N., Sudakova I. G., Garyntseva N.V., Tarabanko V.E., Yatsenkova O.V., Djakovitch L., Rataboul F. Processes of catalytic oxidation for the production of chemicals from softwood biomass. Catalysis Today. 2021. Vol. 375. P. 132-144.

7. Heithes Ed. C., Dimmel D. R. Schemidt. Lignin and Lignans. Adwances in Chemistry, CRS Press, Taylor and Francis Group. 2010. 651 p.

8. Xu C., Arancon R.A.D., Labidi J., Luque R. Lignin depolymerisation strategies: towards valuable chemicals and fuels. Chemical Society Reviews. 2014. Vol. 43. P. 7485-7500.

9. Li C., Zhao X., Wang A., Huber G. W., Zhang T., Catalytic Transformation of Lignin for the Production of Chemicals and Fuels. Chemical Reviews. 2015. Vol. 115. P. 11559-11624.

10. Schutyser W., RendersT., Van den Bosch S., Koelewijn S.F, Beckham G. T., Sels B. F. Chemicals from lignin: an interplay of lignocellulose fractionation, depolymerisation, and upgrading. Chemical Society Reviews. 2018. V. 47 (3). P. 852-908.

11. Kuznetsov B.N., Vasilyeva N. Yu., Kazachenko A. S., Levdansky V.A., Kondrasenko A.A., Malyar Yu.N., Skvortsova G.P., Lutoshkin M. A. Optimization of the process of abies ethanol lignin sulfation by sulfamic acid - urea mixture in 1,4-dioxane medium. Wood Science and Technology. 2020. Vol. 54. P. 365-38.

12. Stephanie Laurichesse, Luc Averous. Chemical modification of lignins: Towards biobased polymers. Progress in Polymer Science. 2014. Vol. 39(7). P. 1266-1290.

13. Johansson A., Aaltonen O., Ylinen P. Organosolv pulping - methods and pulp properties. Biomass. 1987. Vol 13(1). P. 45-65.

14. Sandrine Bouquillion, Jacques Muzart, Catherine Pinel, Franck Rataboul; Palladiumcatalyzed telomerization of butadiene with polyols from mono to polysaccharies. Top Curr Chem. 2010. Vol. 295, P. 93-119.

15. Julien Mesnager, Claude Quettier, Anne Lambin, Frank Rataboul, Alain Perrard and Catrine Pinel. Telomerization of butadiene with starch in water: role of the surfractants. Green Chemistry. 2010. Vol. 12. P. 475-482

16. Kazachenko A. S., Baryshnikov S. V., Chudina A.I., Malyar Yu.N., Sychev V. V., Taran O.P., Dyakovich L., Kuznetsov B.N Hydrogenation of wood and ethanolignins with molecular oxygen in 
supercritical ethanol on a bifunctional catalyst Ru/C. Chemistry of plant raw materials. 2019. Vol. 12(4). P. 15-26.

17. Yunqiao Pu, Shilin Cao and Arthur J. Ragauskas. Application of quantitative ${ }^{31} \mathrm{P}$ NMR in biomass lignin and biofuel precursors characterization. Energy Environ. Sci. 2011. Vol. 4, P. 31543166. 